\title{
An Examination of the Correlation between South African Grade 12 students' Mathematics Self-Concept and their Academic Achievement
}

\author{
James Bill Ouda \\ Masinde Muliro University of Science and Technology, Kenya \\ https://orcid.org/0000-0001-9492-4586 \\ Tawanda Runhare, Ndileleni Mudzielwana, \\ Hasina Cassim and Shonisani Agnes Mulovhedzi \\ University of Venda, South Africa \\ https:// orcid.org/0000-0001-6142-7858 \\ https://orcid.org/0000-0003-1212-0483 \\ https:// orcid.org/0000-0002-5168-8656 \\ https://orcid.org/0000-0002-8355-3377
}

\begin{abstract}
This study measured the correlation between mathematics selfconcept and academic achievement of students at four schools in Vhembe District, South Africa. The study targeted Grade 12 candidates for the South African National Senior Certificate (matric). A sample of 236 respondents - 112 boys and 124 girls - was selected from four schools using purposive and stratified random sampling. Two schools were in a rural area and two in an urban area. A questionnaire that included items from the Academic Self-Concept Questionnaire, and document analysis, were used to measure mathematics self-concept and academic achievement. Each respondent's mathematics achievement score was determined by averaging their mathematics scores over three consecutive terms. The multiple linear regression model and one-way analysis of variance (ANOVA) were used to test the hypotheses. The results of the study show that mathematics self-concept positively and significantly predicted academic achievement. Based on findings, the study makes recommendations for effective methods that teachers and other stakeholders can employ to increase students' mathematics self-concept and boost students' academic achievement.
\end{abstract}

Keywords: mathematics self-concept; academic achievement; mathematics; correlation 


\section{Introduction}

Achievement in mathematics is a prerequisite for deciding to enrol in courses related to science and technology, not only in South Africa, but the world over (MacGregor, 2009; Blaine, 2009). Self-concept is considered to be a predictor of student academic achievement and subject choices (Trautwein et al., 2006; Schnyder \& Niggli, 2006). Studies have also found that students' mathematics achievement has some correlation with their achievement in sciences, especially at high school and tertiary levels (Trautwein et al., 2006). Students with positive attitudes towards mathematics give more academic time to the subject, which can, in turn, positively influence achievement (Trautwein et al., 2006).

The view that most of the outcomes of learning are a result of intra and interpersonal factors is evident from research that explores factors that influence school achievement (MacIntyre \& Ireson, 2002). Mathematics is not an exception in this regard. Teacher motivation, a positive perception of schooling, classroom atmosphere, self-esteem, resilience in academic engagement, anxiety, social and emotional school adjustment are some of the personal factors that have bearing on students differences in academic achievement. With regard to mathematics, Erdogan and Sengul (2014) tested students' learning anxiety and found that "children became more anxious about Mathematics testing situations as they progress through school". The age and grade level of students determines the level of influence of anxiety on student achievement in examinations (Erdogan \& Sengul, 2014).

Research in the field of learning mathematics identified several variables, namely student resilience, socioeconomic background, parental influence and provision of subject-related resources in both the school and the home, which influence mastery of cognitive skills for mathematics in Grade 12 students. Mwangi and Githua (2003) state that the provision of learning material, pressure from family members, and the language of the tests influence the performance of students in mathematics. According to Nagy et al. (2010), the cultural context to which individuals are exposed contributes to self-concept formation through exposure to norms, such as gender-role stereotypes.

MacGregor (2009) observes that, in South Africa, mathematics skills and achievement are important for all students in their schooling. It is a prerequisite for any postsecondary career development, even in fields that are not related to mathematics, science and technology. The minimum compulsory requirement of the National Senior Certificate is a $40 \%$ pass in Grade 12 in mathematics. According to MacGregor (2009) and Blaine (2009), this requirement, though a necessity, seems to militate against massive skills development in the country, because of low mathematics achievement by both high school and higher education students. This paper examines the relationship between high school students' self-concept and actual achievement in mathematics, based on a study of four schools in Vhembe District of Limpopo province in South Africa.

\section{Literature Review}

Mathematics self-concept refers to students' perceptions of their skills and interest in and capability of learning mathematics (Liu et al., 2005). Liu et al. (2005) point out that mathematics self-concept is a product of confidence, as well as effort. 
Confidence refers to the feeling that students have in relation to their ability in a subject, while effort refers to the amount of physical and mental energy dedicated to the study of mathematics. Mathematics self-concept, therefore, refers to academic self-concept, but with a bias toward mathematics, and is a product of a students' effort and confidence in mathematics. Though some studies highlight the link between academic self-concept and achievement (Kwena, 2007; Osei, 2014), they have not specifically isolated mathematics self-concept. Other studies in the field have determined that there are significant relationships between academic self-concept and gender, as well as between cooperative learning and performance in the science subjects (Momanyi et al., 2011; Visi, 2015)

Studies reveal the existence of gender differences in self-concept, which has an impact on student learning and achievement at school (Visi, 2015). Boys have been found to have higher self-concept in mathematics, while girls tend to have higher self-concept in languages (Nagy et al., 2010). Visi (2015) also observed that male secondary school students in Namibia had a more positive attitude about mathematics classroom learning situations than their female counterparts, and that students of a particular gender have more favourable perceptions about the subject when they are taught by a teacher of the same gender. A similar study in Ghana, by Obilor (2011) in relation to applied sciences, reveals gender differences in learning aspirations and outcomes in tertiary students, which favoured female students over their male counterparts. Trautwein et al. (2006) found out that most teachers held gender-informed perceptions about their students, especially in mathematics, sciences and technology. Students showing a positive attitude towards a subject tend to be motivated, self-regulated and more efficacious in content mastery than those reflecting negative feelings (Trautwein et al., 2006).

Vaughan (2002) compared students in individual and cooperative academic engagement in classrooms, and concluded that there were more gains when students studied mathematics in cooperative teams than as individuals. In the same vein, Manger and Eikeland (1998) had earlier found that the individualised approach to learning mathematics resulted in students memorising conceptions of the subject, while learning in cooperative teams helped them to perceive mathematics as a creative and applicable subject. This means that allocating students to groups has the potential of boosting the collective self-concept of students, which is a catalyst for positive achievement in mathematics learning. Engaging students in cooperative groups provides them with the opportunity to share ideas, freely ask each other questions, express their thoughts, justify their answers and debate processes (Hellum-Alexander, 2010; Geist, 2010)

Zahra et al. (2010) studied whether different types of self-concept of individual students, such as academic, physical, and social self-concept, were correlated with their academic achievement. In their study, 1,500 female university degree students in Islamabad who completed a questionnaire were selected through a two-stage cluster sampling technique. The questionnaire by Marsh (1992) was used to collect data on self-concept. Factor analysis and Kendalls-Tau-b revealed that social and physical self-concepts were not related to academic achievement. In contrast, the relationship between academic self-concept and academic achievement was found to be significant, with a weak correlation. 
A study by Kwena (2007), on factors that influence academic performance of primary school students in Bondo District, Kenya, found that the relationship between academic self-concept and academic achievement was significant and positive. The sample comprised 972 students, of whom 497 were male and 475 were female. The focus was on primary school students of Class 6 and Class 8 in a rural area, and considered academic achievement in all subjects. Data were collected using academic self-concept ladders for academic self-concept, and questionnaires for other factors. The possibility of generalizing the results is limited, and findings cannot be extended to students in secondary or primary school, or in an urban environment.

\section{Problem Statement}

Mathematics forms the basis of most scientific subjects and, therefore, finds its application in several fields. Hence, performance in mathematics is critical at all levels of education. A good score in mathematics is also a prerequisite for most courses offered by science-learning colleges and universities. MacGregor (2009) observes that, in South Africa, mathematical skills and achievement are important for all students. It is a prerequisite for any post-secondary career development, even in fields that are not related to mathematics, science and technology. Studies have underlined the link between academic self-concept and achievement (Erdogan \& Sengul, 2014; Kwena, 2007; Osei, 2014), though they have not specifically isolated the role of mathematics self-concept. Other studies in the field have found significant relationships between academic self-concept and gender, and achievement in science subjects (Manger \& Eikeland, 2006; Visi, 2015).

In South Africa, the minimum requirement of the National Senior Certificate is a $40 \%$ pass in Grade 12 mathematics. This requirement, though a necessity, seems to militate against massive skills development in the country, because of low mathematics achievement by both high school and higher education students (MacGregor, 2009; Blaine, 2009). This trend of low mathematics achievement may be inverted if the factors that lead to low mathematics achievement can be understood. Once the factors have been identified, devising a plan to overcome the barriers is key to helping students succeed.

Research on the relationship between academic self-concept and mathematics achievement report contradictory findings. Some studies report a positive correlation, while others found no correlation. Due to the contradictory findings and limited information in the literature on the link between academic selfconcept and mathematics achievement, the researchers of this study sought to examine the extent to which the mathematics self-concept of 236 matric candidates at four South African schools was related to their actual achievement in mathematics.

\section{Hypothesis}

This study was premised on the following hypotheses:

$\mathrm{H}_{0} 1$ : Mathematics self-concept does not significantly predict academic achievement of Grade 12 students.

$\mathrm{H}_{0}$ 2: There are no significant gender differences for mathematics self-concept and academic achievement of Grade 12 students. 
$\mathrm{H}_{0} 3$ : There are no significant differences in mathematics self-concept and academic achievement of Grade 12 students in rural and urban schools.

\section{Methodological Approach}

This study was conducted at four schools using a correlational research design that involved the measurement of two or more variables and the relationship between or among those variables (Stangor, 2011). The main reason for using this design was because it involves the measurement of variance on the dependent variable relative to variance on the predictor variable(s). No variables were manipulated, and student examinations were used to measure academic achievement. It was presumed that the dependent variable would be determined, to some extent, by the independent variable; thus, the study drew conclusions based on the predictive levels of each of the independent variables on the dependent variable. In this case, the link between students' mathematics selfconcept and academic achievement was investigated.

\subsection{Target Population}

The study targeted 4,321 Grade 12 students (2,074 boys and 2,247 girls) in secondary schools in the Vhembe District of South Africa. Students in Grade 12 were chosen for the study because they had already completed 12 years of schooling and were likely, by this time, to have formed a well-defined academic self-concept. Students in Grade 12 were also preferred because they had already chosen their matric subjects, were in their final year of school, and could be expected to be well-established in their studies.

\subsection{Sample and Sampling Procedures}

Purposive and stratified random sampling approaches were used to select the sample. Two rural schools and two urban schools were selected using purposive sampling. The location of the school, the gender of the students, who had to be in Grade 12 and have mathematics as a subject, were considered. Grade 12 was chosen through purposive sampling. Students in Grade 12 were selected through stratified random sampling. Gender was used to stratify the participants (Stangor, 2011).

The sample size was arrived at by applying the formula of Yamane, as cited in Israel (1992). Using the formula, a sample size of 236 was obtained, which comprised Grade 12 candidates. In terms of gender, 112 (47\%) were male and 124 $(53 \%)$ were female. In terms of location, 124 students (52.1\%) were drawn from rural schools and $114(47.9 \%)$ were enrolled at urban schools. The sampled students were, therefore, almost balanced in terms of gender and location of their schools - there were slightly more girls at rural schools. There were two students whose data could not be captured. All the sampled respondents from the four schools were due to sit for the South African matric or National Senior Certificate at the end of 2012.

\subsection{Research Instruments}

Questionnaires and document analysis were used to obtain data for this study. Mathematics self-concept was measured using a questionnaire that included items from the Academic Self-Concept Questionnaire. The questionnaire was 
analyzed by research professionals who critically reviewed the items and provided feedback in the form of ideas for revisions, insertions, and deletions, to ensure content validity. Teachers at secondary schools were also consulted, because they are knowledgeable about what is appropriate for students at various levels of study. The researchers then tweaked the items based on these experts' recommendations. In addition, a pilot study was conducted, and the feedback was used to make the necessary adjustments to improve the validity of the questionnaire.

The items were tested for internal consistency using Cronbach's alpha to measure the questionnaire's reliability, and the coefficients obtained per sub-scale were used to compute the overall instrument reliability. The Cronbach coefficient of reliability of the instrument was given as between 0.74 and 0.89 . The instrument was piloted with a group of 30 Grade 12 secondary school students, and the overall reliability of the instrument was calculated to be 0.79 .

\subsection{Data Collection Procedures}

Before data collection at the four schools, permission to conduct the study was obtained from the relevant gatekeepers, including the Department of Education. The research team visited schools to explain the purpose and expected outcomes of the study to the students and schoolteachers. In order to uphold confidentiality, it was clarified that the reporting of the results of the study would be anonymous and, therefore, participants were instructed to refrain from writing their names on the questionnaire.

\subsection{Data Analysis}

Data that were collected were coded and keyed into a computer for analysis using Statistical Package for Social Sciences (SPSS). The data were analyzed using both descriptive and inferential statistics. The following null hypotheses were tested at $a=0.05$.

$\mathrm{H}_{0} 1$ : Mathematics self-concept does not significantly predict academic achievement of Grade 12 students (statistical test: multiple linear regression).

$\mathrm{H}_{0} 2$ : There are no significant gender differences for mathematics self-concept and academic achievement of Grade 12 students (statistical test: independent sample t-test).

$\mathrm{H}_{0} 3$ : There are no significant differences in mathematics self-concept and academic achievement of Grade 12 students in rural and urban schools (statistical test: one-way analysis of variance [ANOVA].)

\section{Results}

\subsection{Demographic Data}

The sampled schools were classified into rural and urban location. In total, the sample consisted of 112 (47.46\%) male and 124 (52.54\%) female Grade 12 students from four (two rural and two urban) secondary schools in Vhembe District. The students' demographic data is shown in Table 1. 
Table 1. Distribution of sample by location of school

\begin{tabular}{lllllll}
\hline Location & Boys & Percentage & Girls & Percentage & Total & Percentage \\
\hline Rural & 60 & 53.57 & 65 & 52.41 & 125 & 53.00 \\
Urban & 52 & 46.43 & 59 & 47.59 & 111 & 47.00 \\
Total & 112 & 100.00 & 124 & 100.00 & 236 & 100.00 \\
\hline
\end{tabular}

Table 1 shows that the variance of location of schools was not significant and, therefore, it would not have contributed to differences in mathematics selfconcept and academic achievement of students.

\section{Hypothesis 1}

The study's null hypothesis assessed the extent to which mathematics self-concept predicts academic achievement of Grade 12 students in Vhembe District. The null hypothesis that was tested was as follows: Mathematics self-concept does not significantly predict academic achievement of Grade 12 students. The predictive levels of the domains of mathematics self-concept were tested using multiple linear regression analysis.

Table 2. ANOVA for mathematics self-concept model

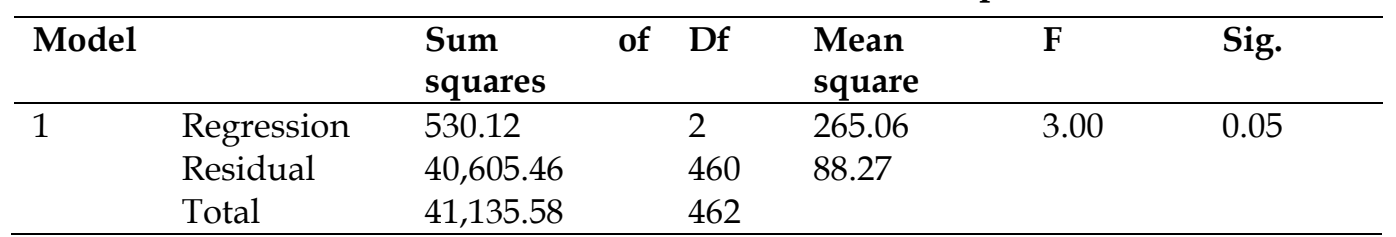

Df - Degrees of freedom, F-statistic is a ratio of two variances, Sig. - statistically significant result

Table 2 reports the ANOVA for the academic self-concept regression model. The analysis in Table 2 shows that the predictive value of academic self-concept is statistically significant, $F(2,460)=3.00, p=0.05$. The null hypothesis is, therefore, rejected.

\section{Hypothesis 2}

The second hypothesis focused on gender differences related to students' mathematics self-concept and academic achievement. The tested null hypothesis stated the following: There are no significant gender differences in mathematics self-concept and academic achievement of Grade 12 students.

To test the hypothesis, an independent sample t-test was carried out for the study variables. The findings show no gender differences in terms of students' mathematics self-concept and academic achievement. The null hypothesis is, therefore, not rejected. The findings are presented in Table 3. 
Table 3. Mean differences for mathematics self-concept and academic achievement by gender

\begin{tabular}{|c|c|c|c|c|c|c|c|c|}
\hline & & \multicolumn{4}{|c|}{$\begin{array}{cc}\text { Levene's test } & \text { t-test for } \\
\text { for equality } & \text { equality of } \\
\text { of variances } & \text { means }\end{array}$} & \multirow[t]{2}{*}{$\begin{array}{l}\text { Sig. (2- } \\
\text { tailed) }\end{array}$} & \multirow[t]{2}{*}{$\begin{array}{l}\text { Mean } \\
\text { diff- } \\
\text { erence }\end{array}$} & \multirow{2}{*}{$\begin{array}{l}\text { Std. } \\
\text { error } \\
\text { diff- } \\
\text { erence }\end{array}$} \\
\hline & & $\bar{F}$ & Sig. & $\mathrm{T}$ & $\overline{D f}$ & & & \\
\hline $\begin{array}{l}\text { Academic } \\
\text { achievement }\end{array}$ & $\begin{array}{l}\text { Equal variances } \\
\text { assumed }\end{array}$ & 0.13 & 0.72 & 0.85 & 461 & 0.40 & 0.76 & 0.89 \\
\hline $\begin{array}{l}\text { Mathematics } \\
\text { self-concept }\end{array}$ & $\begin{array}{l}\text { Equal variances } \\
\text { assumed }\end{array}$ & 0.01 & 0.92 & -0.60 & 461 & 0.55 & -0.33 & 0.54 \\
\hline
\end{tabular}

The findings in Table 3 indicate that the mean differences in academic achievement and mathematics self-concept were not statistically significant, assuming equal variances for academic achievement, $\mathrm{t}(461)=0.85, \mathrm{p}=0.89$ and $\mathrm{t}(461)=-0.60, \mathrm{p}=0.54$, for mathematics self-concept. Thus, there appears to be no significant gender differences in mathematics self-concept and academic achievement. Not only were the differences in means marginal, but they were also statistically insignificant. Macharia (2011) and Agarawal and Kumar (2015) revealed similar findings in their investigations of gender differences in chemistry and mathematics achievement respectively, hence, the null hypothesis was not rejected.

\section{Hypothesis 3}

The third hypothesis focused on determining differences between respondents' mathematics self-concept and academic achievement based on the location of their school. The following null hypothesis was tested: There are no significant differences in mathematics self-concept and academic achievement between students at rural and urban schools. A one-way ANOVA was used to test the hypothesis. The results are presented in Table 4 .

Table 4. ANOVA of mathematics self-concept and academic achievement

\begin{tabular}{llrllll}
\hline & & $\begin{array}{c}\text { Sum of } \\
\text { squares }\end{array}$ & Df & $\begin{array}{c}\text { Mean } \\
\text { square }\end{array}$ & F & Sig. \\
\hline $\begin{array}{l}\text { Academic } \\
\text { achievement }\end{array}$ & $\begin{array}{l}\text { Between } \\
\text { groups }\end{array}$ & $10,080.13$ & 2 & 5040.07 & 74.66 & 0.00 \\
& $\begin{array}{l}\text { Within } \\
\text { groups }\end{array}$ & $31,055.45$ & 460 & 67.51 & & \\
& $\begin{array}{l}\text { Total } \\
\text { Mathematics }\end{array}$ & $41,135.58$ & 462 & & & \\
Between & 11.82 & 2 & 5.91 & 0.16 & 0.72 \\
& $\begin{array}{l}\text { groups } \\
\text { Within }\end{array}$ & $14,595.42$ & 460 & 31.73 & & \\
& $\begin{array}{l}\text { groups } \\
\text { Total }\end{array}$ & $14,607.24$ & 462 & & & \\
\hline
\end{tabular}

Significant differences existed between the means of academic achievement of schools based on location $-\mathrm{F}(2,460)=74.66, \mathrm{p}<0.01$. The mean differences for mathematics self-concept $-\mathrm{F}(2,460)=0.16, \mathrm{p}=0.72$ - between schools based on location were, however, statistically insignificant. The differences between locations of schools in relation to mathematics self-concept were statistically 
insignificant. These results show that the level of mathematics self-concept of students is not determined by the location of their schools, whether urban or rural.

\section{Discussion}

The first hypothesis relates to the extent to which a student's mathematics selfconcept predicts their academic achievement. The two variables had a positive and significant relationship. These findings suggest that attempts to strengthen students' mathematics self-concept should be intensified, as doing so will boost their confidence and, hence, lead to improved academic achievement. If students' confidence is strengthened, they will be more inclined to exert greater effort to learn mathematics. These findings corroborate those of Ajogbeje (2010), Kwena (2007), and Macharia (2011). In a sample of secondary school students, Ajogbeje (2010) found a strong link between students' academic self-perception and their mathematics performance. In her study of elementary school students, Kwena (2007) found a link between academic self-concept and mathematics achievement of primary school students These findings of previously cited authors, therefore, suggest that the level of education does not necessarily influence the relationship between self-concept and academic achievement. Students' personal beliefs about their capability to learn influence their motivation and learning (Gwirayi \& Shumba, 2007). Trautwein et al. (2006) concur that students with a positive attitude towards mathematics give more academic time to the subject, which, in turn, positively influences achievement. A study by Chang and Lin (2017) demonstrated that students with higher academic self-concept tended to invest more time in learning activities related to learning the corresponding subject.

The second hypothesis focused on gender differences in relation to mathematics self-concept and academic achievement. The findings indicate that male and female students were not significantly different in mathematics self-concept and academic achievement. These findings correspond with those reported by other researchers in the field (Agarawal \& Kumar, 2015; Macharia, 2011). Agarawal and Kumar (2015), in their study on gender differences in academic self-concept of boys and girls, found no differences between the two genders. Furthermore, the results of Macharia's (2011) investigation into the effects of gender and mathematics ability on academic performance, found no significant difference in the performance of male and female students in chemistry. Thus, these studies imply that, environment notwithstanding, gender does not have any significant effect on mathematics achievement.

The third hypothesis focused on determining differences in mathematics selfconcept and academic achievement in relation to the location of school. Findings reveal that the location of the school - whether in a rural or urban area - had a significant influence on mathematics self-concept and academic achievement. These findings are similar to those of Baran and Maskan (2011) and Srivastara and Joshi (2015). Baran and Maskan (2011) investigated the link between students' academic self-concept and factors such as location of school, school type, gender, and family background. Students in vocational high schools had a lower selfconcept than students at other institutions. Srivastara and Joshi (2011) conducted a study on the effect of school and area on academic self-concept and academic

http://ijlter.org/index.php/ijlter 
achievement, and found that adolescents in schools in urban centers had greater academic self-concept and achievement than those at schools in rural areas.

\section{Conclusions and Recommendations}

The study findings demonstrate that mathematics self-concept plays a significant role in students' academic performance and, therefore, self-concept should be encouraged. It is also worth noting that gender differences do not influence how mathematics self-concept affects academic achievement of students. The findings reveal that the location of the school, that is, whether in a rural or urban area, had a significant influence on mathematics self-concept and academic achievement of students.

Based on the findings, the study recommends the following:

- Mathematics teachers should be empowered through training to improve students' mathematics self-concept and their confidence regarding learning mathematics, which should improve their academic performance in the subject.

- Mentoring programs should be introduced to expose students to successful role models and motivational speakers, who could boost their mathematics self-concept and encourage them to work hard in mathematics. Doing so is likely to improve students' academic achievement.

\section{References}

Agarawal, M., \& Kumar, A. T. (2015). Academic achievement and self-concept of secondary level students. Journal of Educational Psychology, 1(3), 26-33.

Ajogbeje, J. O. (2010). Mathematics achievement among secondary school students in AdoEkiti, Nigeria. Nigerian Journal of Guidance and Counseling, 15(1), 261-278.

Babbie, E. R. (1990). Survey research methods. Belmont, CA: Wadsworth.

Baran, M., \& Maskan, A. K. (2011). A study of relationships between academic selfconcepts, some selected variables, and physics course achievement. International Journal of Education, 3(1), E2. https://doi.org/10.5296/ije.v3i1.586

Blaine, S (2009, May 12). South Africa: No one accepts blame for poor maths results. Business Day, p. 1.

Chang, C.Y., \& Lin, P.L. (2017). The relationship between science achievement and selfconcept among gifted students from the Third International Earth Science Olympiad. EURASIA Journal of Mathematics Science and Technology Education, 13(7), 3993-4007. https://doi.org/10.12973/eurasia.2017.00768a

Erdogan, F., \& Sengul, S. (2014). A study on the elementary school students' mathematics self-concept. Procedia - Social and Behavioral Sciences, 152, 596-601. https://doi.org/10.1016/j.sbspro.2014.09.249

Geist, E. (2010). The anti-anxiety curriculum: Combating math anxiety in the classroom. $\begin{array}{llll}\text { Journal of Instructional } & \text { Psychology, }\end{array}$ https://www.researchgate.net/publication/281089312

Gwirayi, P., \& Shumba, P. (2001). Students' self-concept and academic achievement in Zimbabwe: A preliminary study. Journal of Psychology in Africa, 17(1), 119-122. https://doi.org/10.1080/14330237.2007.10820155

Hellum-Alexander, A. (2010). Effective teaching strategies for alleviating math anxiety and increasing self-efficacy in secondary students [Master's dissertation, Evergreen State College]. 
Israel, G. D. (1992). Sampling the evidence of extension program impact. Program Evaluation and Organizational Development, IFAS, University of Florida, PEOD-5. http://edis.ifas.ufl.edu/pdffiles/PD/PD00500.pdf3/6/2011

Kwena, A. J. (2007). An investigation into selected factors on academic self-concept among primary school pupils in Bondo District [Unpublished PhD thesis, Kenyatta University, Nairobi, Kenya].

Liu, W., Wang, C. D., \& Parkins, E. J. (2005). A longitudinal study of students' academic self-concept in a streamed setting: The Singapore context. British Journal of Educational Psychology, 74(4), 567-586. https://doi.org/10.1348/000709905X42239

MacGregor, K. (2009, August 16). South Africa: shocking results from university tests. University World News, Africa Edition. https:/ / www.universityworldnews.com/ post.php?story=20090816082047397

Macharia, R. W. (2011). Investigation of factors influencing academic self-concept and academic achievement among day secondary students in Githobokoni division, Gatundu District [Master's thesis, Kenyatta University, Nairobi, Kenya].

MacIntyre, H., \& Ireson, J. (2002). Within-class ability grouping: placement of learners in groups and self-concept. British Educational Research Journal, 28(2), 249-263. https://doi.org/10.1080/01411920120122176

Manger, T., \& Eikeland, O. (1998). The effect of mathematics self-concept on girls' and boys' mathematical achievement. School Psychology International, 19(1), 5-18. https://doi.org/10.1177/0143034398191001

Marsh, H. W. (1992). Content specificity of relations between academic achievement and academic self-concept. Journal of Educational Psychology, 84(1), 35-42. https:// doi.org/10.1037/0022-0663.84.1.35

Momanyi, J. M., Too, J. K., \& Simiyu, C. (2011). Influence of type of school on academic motivation and academic performance among secondary schools in Kenya. International Journal of Current Research, 7, 23368-23372.

Mwangi, J. G., \& Githua, B. N. (2003). Students' mathematics self-concept and motivation to learn mathematics: relationship and gender differences among Kenya's secondary-school students in Nairobi and Rift Valley provinces. International Journal of Educational Development, 23, 487-499.

Nagy, G., Watt, H. M. G., Eccles, J. S., Trautwein, M., Lüdtke, O., \& Baumert, J. (2010). The development of students' mathematics self-concept in relation to gender: Different countries, different trajectories? Journal of Research on Adolescent, 20(2), 482-506. https://doi.org/10.1111/j.1532-7795.2010.00644.x

Obilor, I. E. (2011). Relationship between self-concept and mathematics achievement of senior secondary students in Port Harcourt Metropolis. Journal of Educational and Social Research, 1(4), 39-46.

Osei, E. (2014). Achievement and motivation, academic self-concept and academic achievement among high school students. European Journal of Research and Reflection in Educational Studies, 2(2), 24-37.

Schnyder, I., \& Niggli, A. (2006). Predicting homework effort: Support for a domainspecific, multilevel homework model. Journal of Educational Psychology, 98, 438456.

Srivastara, R., \& Joshi, S. (2011). The effect of school and area on academic self-concept and academic achievement of adolescents. Delhi Psychiatry Journal, 1(2), 331-336.

Stangor, C. (2011). Research methods for the behavioral sciences ( $4^{\text {th }}$ ed.). Cengage Learning.

Trautwein, U., Lüdtke, O., Köller, O., \& Baumert, J. (2006). Self-esteem, academic selfconcept, and achievement: how the learning environment moderates the dynamics of self-concept. Journal of Personality and Social Psychology, 90(2), 334349. https://doi.org/10.1037/0022-3514.90.2.334 
Vaughan, W. (2002). Effects of cooperative learning on achievement and attitude among students of color. The Journal of Educational Research, 95(6), 359-365. https://doi.org/10.1080/00220670209596610

Visi, N. (2015). The relationship between students' academic self-concept, motivation and academic achievement. Journal of Applied Environmental and Biological Sciences, 5(4), 270-276.

Zahra, A., Arif, M., \& Yousuf, M. (2010). Relationship of academic, physical and social selfconcepts of students with their academic achievement. Contemporary Issues in Educational Research, 3(3), 73-78. https://doi.org/10.19030/cier.v3i3.190 